Original Contribution

\title{
DYNAMICS OF SOME BASIC BLOOD INDICES IN GUINEA FOWL (N. MELEAGRIS) DEPENDING ON THE EGG LAYING PERIOD
}

\author{
D. Penkov ${ }^{1}$, A. Arnaudov ${ }^{2 *}$, M. Nikolova ${ }^{1}$ \\ ${ }^{1}$ Department of Animal Sciences, Agricultural University-Plovdiv, Plovdiv, Bulgaria \\ ${ }^{2}$ Department of Human Anatomy and Physiology, Faculty of Biology, Plovdiv University \\ „Paisii Hilendarski“, Plovdiv, Bulgaria
}

\begin{abstract}
A monitoring study of some main blood parameters of a flock of free-range guinea fowls has been conducted.

The following results (depending on sex and laying intensity) have been established: hemoglobin content - between 145.8 (males - before peak of laying intensity) and $98 \mathrm{~g} / \mathrm{L}$ (females - before the peak of laying intensity), hematocrit - between 43.8 (males - before the peak of laying intensity) and $28.8 \%$ (females before the peak of laying intensity), glucose - between 11.7 (males - before the peak of laying intensity) and $8.24 \mathrm{mmol} / \mathrm{L}$ (females - end of the laying period) and total protein content - between 5.86 (females during the peak of laying intensity) and $3.30 \mathrm{~g} / \mathrm{dL}$ (males - during the peak of laying intensity).
\end{abstract}

Key words: glucose, Guinea fowl, hematocrit, hemoglobin, total protein

\section{INTRODUCTION}

Some biochemical parameters in the blood are largely affected by the physiological strain on the body that may be due to rapid changes in environmental conditions or to intense commercial use. This effect can be observed both in domesticated animals (1-3) and in poultry (46) and others.

Over the last years consumer demand has followed 2 main trends - diversification of food products through consumption of products from exotic species and consumption of products from biological or free-range farming (7-19).

In Bulgaria guinea fowl farming is popular mainly among small-scale producers who raise the poultry under extensive farming conditions (20).

Monitoring some main blood parameters in view of the commercial strain on the body in this poultry species is a practice which is gaining popularity globally while in Bulgaria efforts in this respect are still in their initial stage.

* Correspondence to: A. Arnaudov, ${ }^{2}$ Department of Human Anatomy and Physiology, Faculty of Biology, Plovdiv University, „,Paisii Hilendarski“, Plovdiv, Bulgaria, arny87@abv.bg
The aim of this study is to monitor the dynamics of some blood parameters in freerange guinea hens during the egg-laying period.

\section{MATERIAL AND METHODS}

In 2018 in the Experimental base of the Agricultural University-Plovdiv, a monitoring study of some main blood parameters of a flock of free-range guinea hens was conducted. Blood samples were drawn through the toracica lateral is vein from 6 female and 6 male specimens at 3 different laying stages - before the egg-laying peak (at the beginning of May - laying intensity of $48 \%$ ), during the egg-laying peak (at the end of May - laying intensity of 51\%) and at the end of the egg-laying period (end of June with laying intensity of $27 \%$ ).

Until the time of the test, the blood samples were stored in $3 \mathrm{ml}$ cuvettes with $3.2 \%$ sodium citrate (Vacuette) at temperatures of $4-8^{\circ} \mathrm{C}$. The following parameters were measured: total haemoglobin, haematocrit, glucose and total protein. Total haemoglobin and haematocrit were measured using the Hemo Control haematological analyser, EKF Diagnostic (Germany) and blood glucose was measured using HemoCue Glucose 
201RT Analyser (Sweden). Protein content in blood plasma was determined through refractory using Brix Refractometer RHB32ATC following the method described by (21).

\section{RESULTS AND DISCUSSION}

Table 1 shows a summary of the results from monitoring the four parameters in both sexes during the different periods.

There were considerable differences in hemoglobin levels between the two sexes in all three periods of the study where hemoglobin content in male poultry was higher (by periods: 145.8 compared to $98 ; 142.8$ compared to 114.2 and 132.8 compared to $107.8 \mathrm{~g} / \mathrm{L}$, respectively) and relatively constant during the entire egg-laying period (Figure 1). In female specimens there was an increase in hemoglobin before the egg-laying peak and during the following periods, statistically reliable during the egg-laying peak. A similar trend was observed in hematocrit - male poultry demonstrated higher values during all three of the test periods with reliable differences in the first 2 periods (Figure 2). Unlike hemoglobin, however, no significant differences in hematocrit values between periods could be observed either in the male 1 (43.8, 42.1 and $38.72 \%$, respectively) or in the female poultry $(28.8$, 34.1 and $34.5 \%)$.

Table 1. Values of some biochemical parameters in the blood of guinea fowl in different periods of laying intensity

\begin{tabular}{|c|c|c|c|c|c|c|c|c|}
\hline \multirow[t]{2}{*}{ Periods } & \multicolumn{2}{|c|}{ Hemoglobin-g/L } & \multicolumn{2}{|c|}{ Hematocrit - \% } & \multicolumn{2}{|c|}{ Glucose-mmol/L } & \multirow{2}{*}{$\begin{array}{l}\text { Total } \\
\text { g/dL } \\
\text { Male } \\
\mathrm{x} \pm \mathrm{Sx}\end{array}$} & \multirow{2}{*}{$\begin{array}{l}\text { protein- } \\
\text { Female } \\
\mathrm{X} \pm \mathrm{Sx}\end{array}$} \\
\hline & $\begin{array}{l}\text { Male } \\
\mathrm{x} \pm \mathrm{Sx}\end{array}$ & $\begin{array}{l}\text { Female } \\
\mathrm{x} \pm \mathrm{Sx}\end{array}$ & $\begin{array}{l}\text { Male } \\
\mathrm{x} \pm \mathrm{Sx}\end{array}$ & $\begin{array}{l}\text { Female } \\
\mathrm{x} \pm \mathrm{Sx}\end{array}$ & $\begin{array}{l}\text { Male } \\
\mathrm{x} \pm \mathrm{Sx}\end{array}$ & $\begin{array}{l}\text { Female } \\
\mathrm{x} \pm \mathrm{Sx}\end{array}$ & & \\
\hline $\begin{array}{l}\text { Before the } \\
\text { peak of } \\
\text { laying } \\
\text { intensity }\end{array}$ & $\begin{array}{l}145.8 \\
\pm 1.77 \mathrm{~A}\end{array}$ & $\begin{array}{l}98.00 \pm \\
6.18 \mathrm{AC}\end{array}$ & $\begin{array}{l}43.8 \pm \\
0.66 \mathrm{~A}\end{array}$ & $\begin{array}{l}28.8 \pm \\
1.77 \mathrm{~A}\end{array}$ & $\begin{array}{l}11.02 \pm 0 \\
24 \mathrm{~A}\end{array}$ & $\begin{array}{l}8.98 \pm \\
0.35 \mathrm{~A}\end{array}$ & $\begin{array}{l}4.34 \pm \\
0.09 \mathrm{~A}\end{array}$ & $\begin{array}{l}4.92 \pm \\
0.21 \mathrm{~A}\end{array}$ \\
\hline $\begin{array}{l}\text { Peak of } \\
\text { laying } \\
\text { intensity }\end{array}$ & $\begin{array}{l}142.8 \pm \\
1.98 \mathrm{~A}\end{array}$ & $\begin{array}{l}114.2 \pm \\
1.69 \mathrm{AC}\end{array}$ & $\begin{array}{l}42.1 \pm \\
0.33 \mathrm{~A}\end{array}$ & $\begin{array}{l}34.1 \pm \\
0.48 \mathrm{~A}\end{array}$ & $\begin{array}{l}8.80 \pm \\
0.51 \mathrm{~B}\end{array}$ & $\begin{array}{l}9.28 \pm \\
0.09\end{array}$ & $\begin{array}{l}3.30 \pm \\
0.13 \mathrm{~A}\end{array}$ & $\begin{array}{l}5.86 \pm \\
0.13 \mathrm{~A}\end{array}$ \\
\hline $\begin{array}{l}\text { End of } \\
\text { laying period }\end{array}$ & $\begin{array}{l}132.8 \pm \\
2.67 \mathrm{~A}\end{array}$ & $\begin{array}{l}107.8 \pm \\
6.69 \mathrm{~A}\end{array}$ & $\begin{array}{l}38.72 \pm \\
0.67\end{array}$ & $\begin{array}{l}34.5 \pm \\
2.03\end{array}$ & $\begin{array}{l}11.7 \pm \\
0.35 \mathrm{AB}\end{array}$ & $\begin{array}{l}8.24 \pm \\
0.49 \mathrm{~A}\end{array}$ & $\begin{array}{l}4.34 \pm \\
0.11\end{array}$ & $\begin{array}{l}4.84 \pm \\
0.23\end{array}$ \\
\hline
\end{tabular}

Notice: Significant by $\mathrm{p}<0,05$, as follow: A-A - between the sexes within a period; B-B - males under different periods; C-C - females under different periods

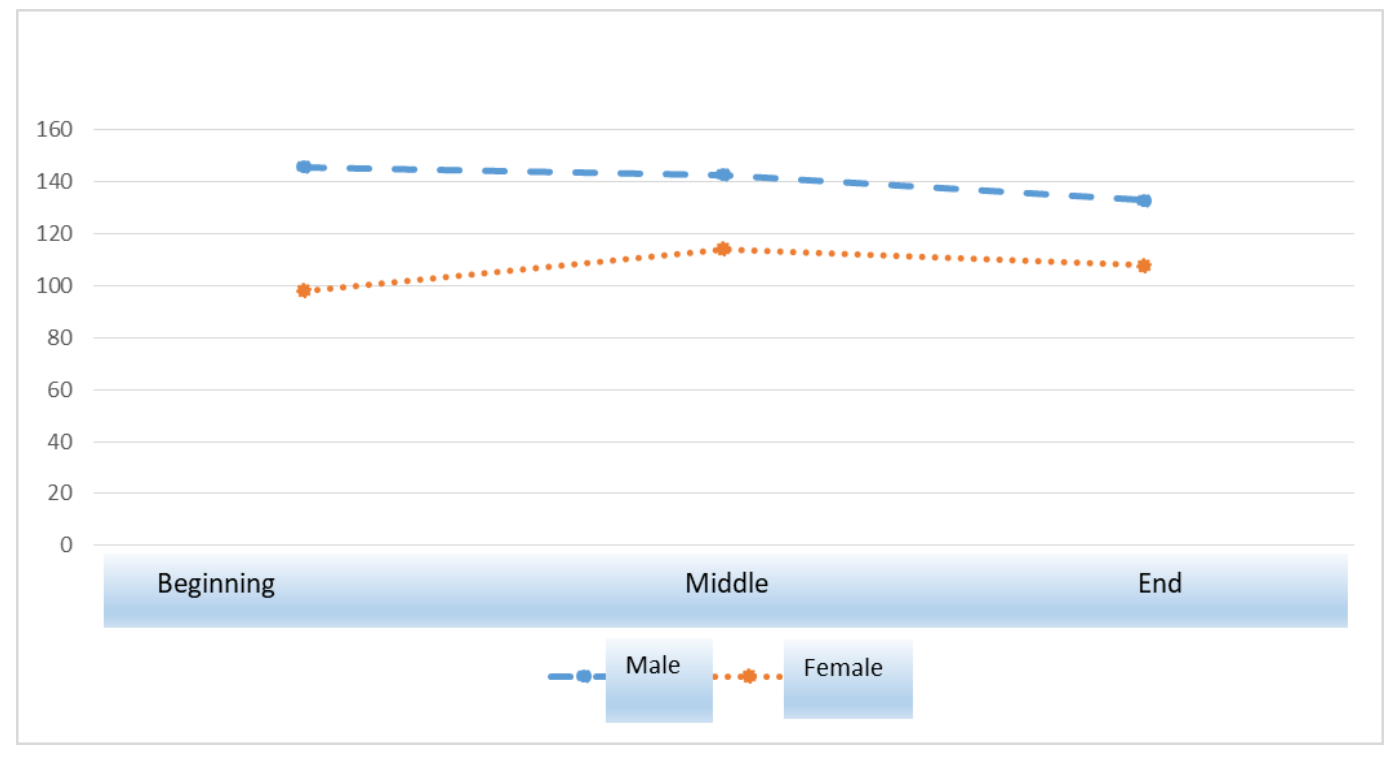

Figure 1. Content of hemoglobin in blood - $\mathrm{g} / \mathrm{L}$ 


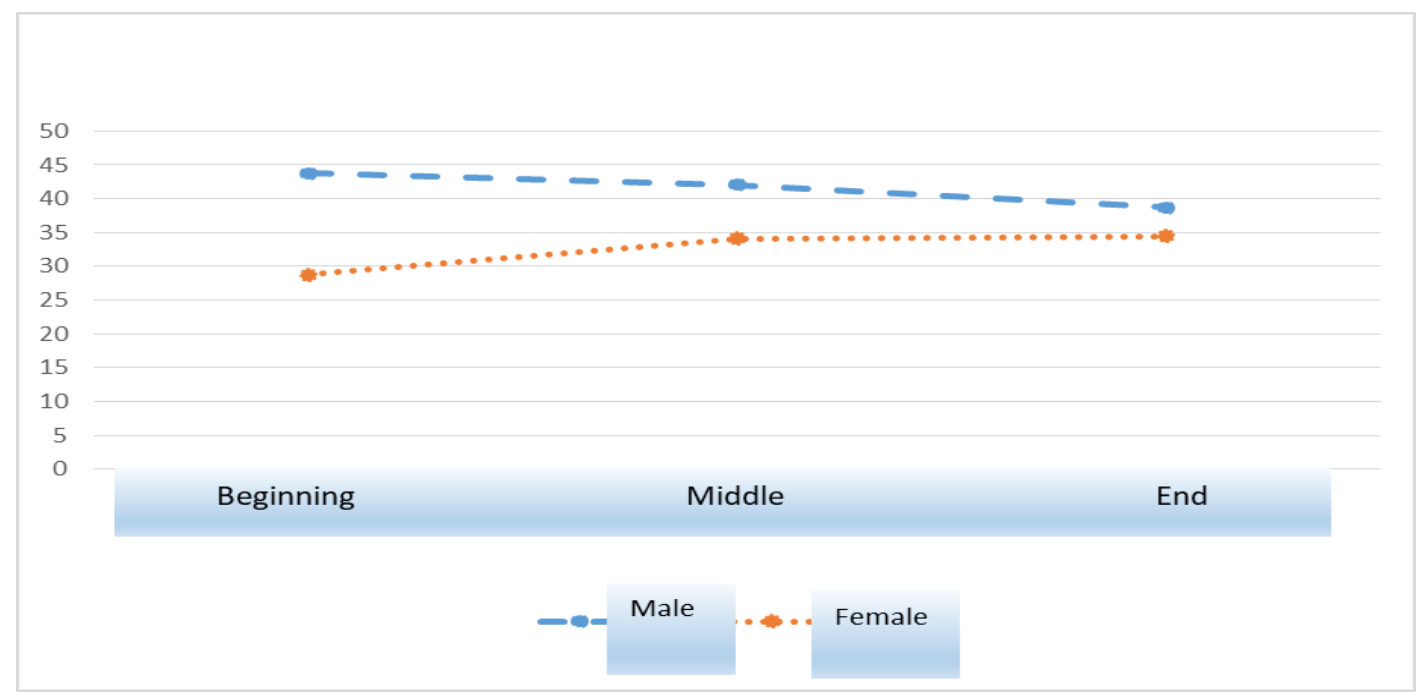

Figure 2. Hematocrit of the blood- \%

The glucose content results revealed some interesting trends (Figure 3). More significant dynamics in its content were observed in male poultry: the lowest values of this parameter were measured during the egg-laying peak $8.80 \mathrm{mmol} / \mathrm{L}$, while in the period before the peak and especially at the end of the egg- laying period (where differences are statistically reliable) values were 11.02 and $11.7 \mathrm{mmol} / \mathrm{L}$, respectively. In female poultry glucose content varied within a shorter range from 8.24 (end of the egg-laying period) to $9.28 \mathrm{mmol} / \mathrm{L}$ (egg-laying peak) without reliable differences between periods.

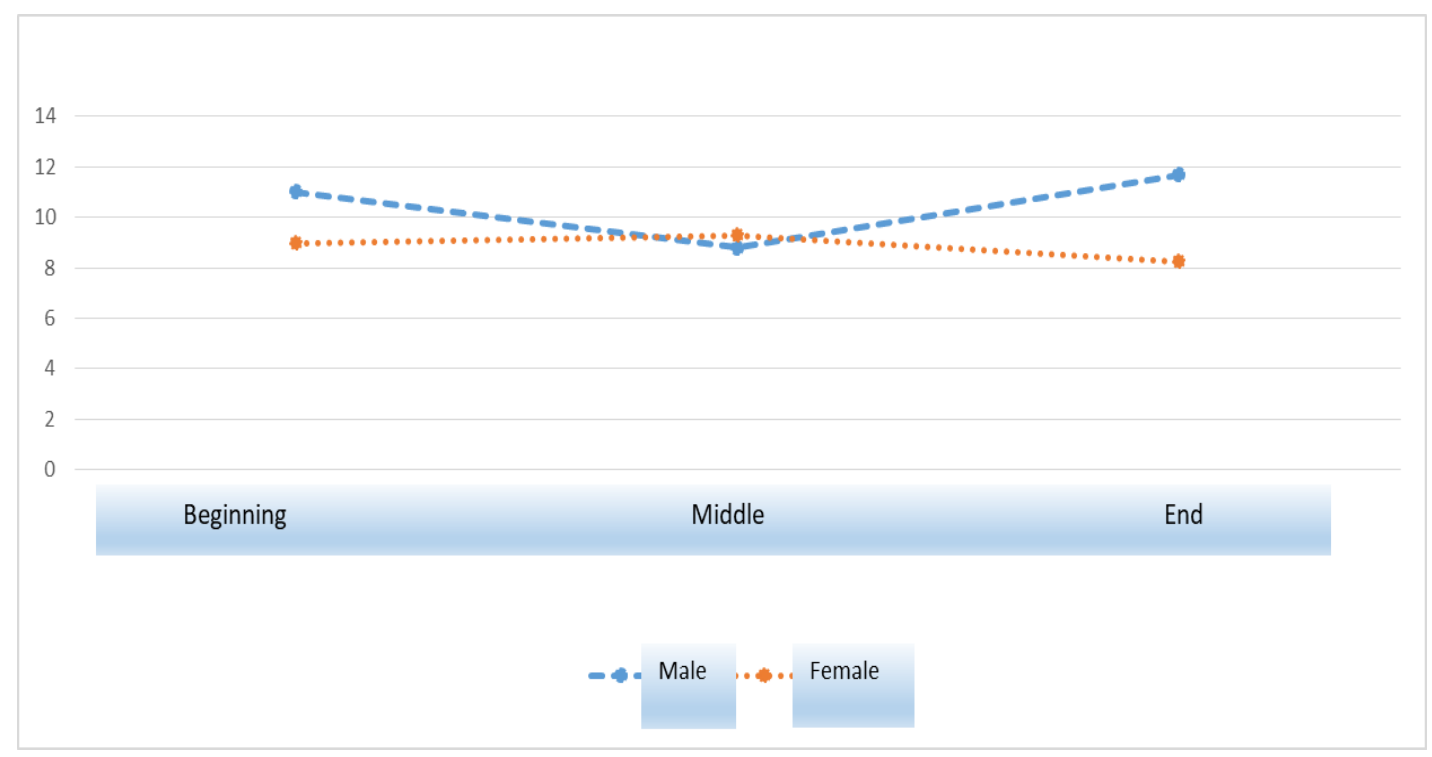

Figure 3. Content of glucose in blood - $\mathrm{mmol} / \mathrm{L}$

Total protein content in male poultry was lower when compared to female specimens during the entire test period (Figure 4). The greatest and most reliable difference (3.30 compared to $5.86 \mathrm{~g} / \mathrm{dL}$ ) was observed during the egg-laying peak while at the beginning and the end of the test differences were less significant - 4.34 compared to 4.92 (statistically reliable) and 4.34 compared to $4.84 \mathrm{~g} / \mathrm{dL}$, respectively. The higher protein content in female poultry could be explained by the fact that in order to form the protein fraction in the eggs (both in the egg yolk and in the egg-white in particular) birds used more protein which is mainly delivered through the bloodstream. This proposition is supported by the fact that the period with highest laying intensity coincided with the highest values of total protein measured. 


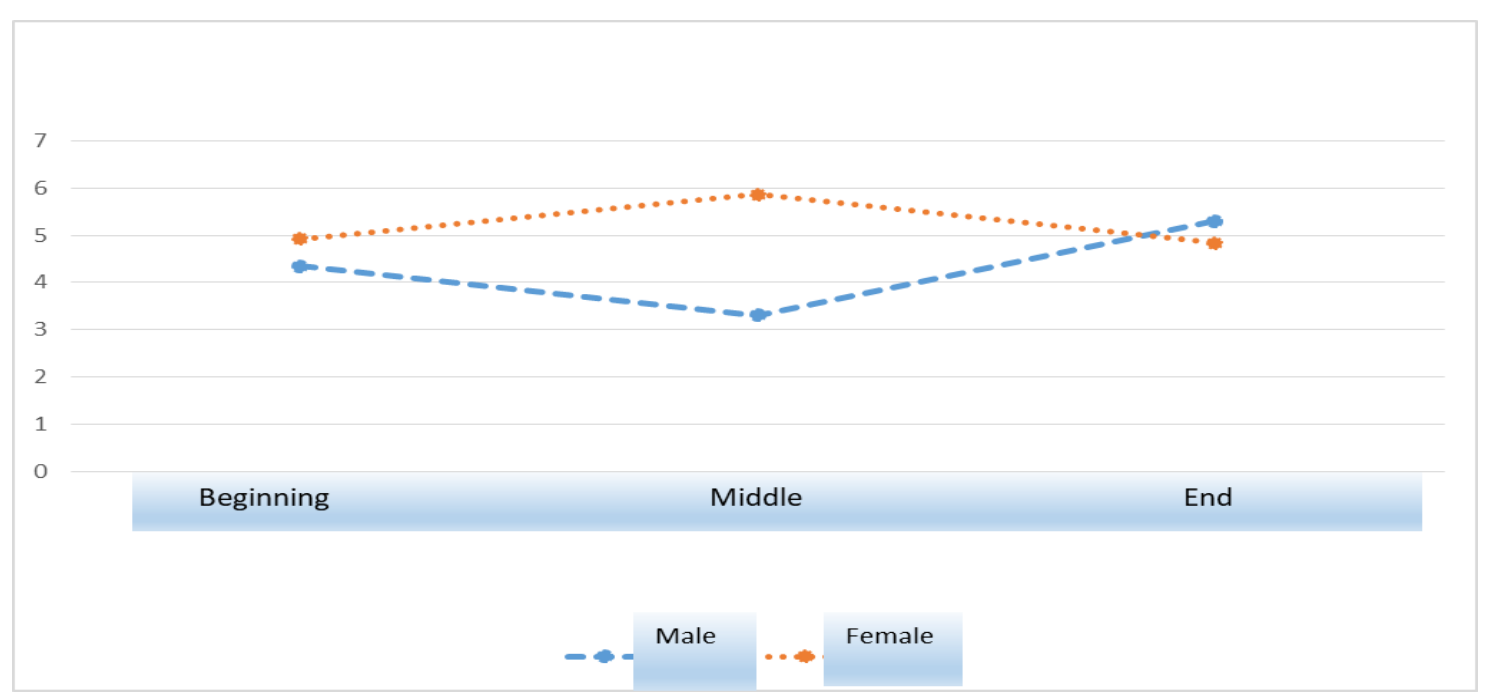

Figure 4. Content of total protein in the blood $-\mathrm{g} / \mathrm{dL}$

Various authors have studied the effects of sex and farming technology on the hematological and biochemical parameters of blood samples from guinea fowl (22-27).

Hemoglobin content results obtained during our study are in support of the prevailing opinion that male poultry have higher parameter values. For instance, Nalubamba et al. (24) note that despite differences in content between the different varieties of the same species in Nigeria the average results of clinically healthy male poultry were around 13, whereas those of female specimens were around $12 \mathrm{~g} / \mathrm{dL}$. The same authors draw attention to the fact that the values of this parameter are significantly affected by the combined effects of general health (presence of helminths) and the color variety. The authors state that identical variations can be observed in hemoglobin-related blood elements. Similar trends were established by Oyewale et al. (28) and Orji et al. (29).

According to most authors $(22,23,25)$ sex can affect both hemoglobin and hematocrit parameters, where male animals have higher values.

Although some authors (22) hold the opinion that farming conditions and the productive period do not have a significant influence on blood parameters, most authors disagree with this opinion $(24,25)$. This is true both for glucose content and protein fractions. In their research (30) compared these two parameters in various poultry and found that both albumins and globulins in the blood were higher in female poultry when compared to male specimens and this was particularly true for the guinea fowl species. Our research confirms this theory.

\section{CONCLUSIONS}

Hemoglobin content in blood samples from female guinea fowl at different laying intensity varies between 98 (before the egg-laying peak) and $114 \mathrm{~g} / \mathrm{l}$ (egg-laying peak). In male poultry it is significantly higher during the tested periods - from 132.8 (end of the egg-laying period) to $145.8 \mathrm{~g} / \mathrm{l}$ (before the egg-laying peak).

Hematocrit content follows the same trend as hemoglobin where in female poultry it varies between 28.8 (before the peak) and 34.5\% (at the end of the egg-laying period), whereas in male - between 38.72 (at the end of the egglaying period) and $43.8 \%$ (before the peak).

Glucose content in blood samples from guinea hens varies between 8.24 (end of the egglaying period) and $9.28 \mathrm{mmol} / \mathrm{L}$ (during the egg-laying peak) and in male poultry - between 8.8 (egg-laying peak) and $11.7 \mathrm{mmol} / \mathrm{L}$ (end of the egg-laying period).

Total protein content follows a similar trend to glucose - in guinea fowl it varies between 4.84 (end of the egg-laying period) and $5.86 \mathrm{~g} / \mathrm{dL}$ (during the egg-laying peak) while in male poultry it varies between 3.30 (during the egglaying peak) and $4.34 \mathrm{~g} / \mathrm{dL}$ (before the peak and at the end of the egg-laying period).

The statistically significant differences in the values of most of the tested parameters, which depend both on the sex of the animals and the egg-laying period, prove that they can be used as markers of the level of biological and economic strain on the body. 


\section{REFERENCES}

1. Ivanova R., Hristev, H., Nikolov, V., Batcalov, P., Study on some hematological characteristics of cows of Bulgarian Rhodope cattle breed under lowland conditions, Proc IV Balk Conf Anim Sci, St. Zagora, 398-402, 2009.

2. Gergovska, Z., Ivanova, R., Hristev, H., Comparative study of the values of thyroid hormones, total protein and blood glucose in cows with different physical activity during their dry period. Agr Nauki (BG), 5:169-173, 2013.

3. Bochukov, A., Race, age and sex features of the hematological indexes of goats in autumn. J Mount Agri Balk, 12, 3: 409- 424, 2009.

4. Gerzilov, V., Petrov, P. B., Bochukov A., Effect of force-feeding of fatty liver and serum biochemical parameters in mule ducks. Agro Life Sci J, 2, 1: 193-196, 2013.

5. Gerzilov, V., Nikolov, A., Petrov, P., Bozakova, N., Penchev, G., Bochukov A., 2015, Effect of a dietary herbal mixture supplement on the growth performance, egg production and health status in chickens. $J C$ Eur Agr, 16, 2:10-27, 2015.

6. Straková, E., P. Suchý, Kábelová, R., Vitula, F., Herzig, I., Values of Selected Haematological Indicators in Six Species of Feathered Game. Act Vet Brno, 1,3: 51-56, 2010.

7. Crowe, T. M., Evolution and ecology of Guinea fowl, PhD Thesis, University of Cape Town,1 978.

8. Ayorinde, K. L. and Okaeme, A. N., All year guinea fowl-How feasible?. Afr Farm and Food Proc. March/April, 21-22, 1984.

9. Ayorinde, K. L., Effect of holding room, storage position and duration on hatchability of guinea fowl eggs. Trop Agr (Trinidad), 64: 188-190, 1987a.

10. Ayorinde, K. L., Physical and chemical characteristics of the eggs of four indigenous guinea fowls in Nigeria. Nig J Anim Prod, 14: 125-128, 1987b.

11. Ayorinde, K. L. and Ayeni, J. S. O., Effects of management systems on the fattening of indigenous pearl guinea fowl (Numida meleagris galeata Pallas) in Nigeria. Trop Agr (Trinidad), 64, 3: 185-187, 1987a.

12. Ayorinde, K. L. and Ayeni, J. S. O., Performance of guinea fowl breeders fed varying levels of Cyperus bulb. Nig J. Anim Prod, 14: 139-145, 1987b.

13. Ayorinde, K. L., Ayeni, J. S. O., Oluyemi, J. A., Laying characteristics and reproductive performance of four indigenous helmet guinea fowl varieties (Numida meleagris galeata Pallas) in Nigeria. Trop Agr (Trinidad), 66, 3: 277- 280. 1989.
14. Ayorinde, K.L., Guinea fowl (Numida meleagris) as a protein supplement in Nigeria, World's Poult Sci J, 47:21-26. 1991.

15. Ayorinde, K. L., Genetic and phenotypic correlations of body weight, age at sexual maturity and some egg production traits in two local guinea fowl varieties. Arch Geflugelk, 59,4: 215-219, 1995a.

16. Ayorinde, K. L., Egg production and reproductive performance of local and exotic pearl and their crosses. Nig J Genet, 10: 4753, 1995b.

17. Ayorinde, K. L., Physical and chemical characteristics of the eggs of four indigenous guinea fowls in Nigeria. Nig J Anim Prod, 14: 125-128, 1987.

18. Ayorinde, K. L., Problems and prospects of guinea fowl production in the rural areas of Nigeria. In: Sonaiya EB (eds), Proc Int Work Rur Poult Develop in Afr, Ile Ife, NGA, 106115, 1990.

19. Adeyeye, E. I., Comparative evaluation of the amino acid profile of the muscle and skin of guinea fowl (Numida meleagris) hen, Elixir Appl Chem, 39: 4848-4854, 2011.

20. Nikolova, M., Guinea fowl promising species farmed birds, Ptizevadstvo, 4: 6-8, 2013, (in BG)

21. Andreasen, C. B., Latimer, K. S., Kircher, I. M., Brown, J., Determination of chicken and turkey plasma and serum protein concentrations by refractometry and the biuret method. Avian Dis, 33: 93-96, 1989.

22.Pandian, C., Pandiyan, M. T., Sundaresan, A., Omprakash, A. V. Haematological profile and erythrocyte indices in different breeds of poultry. Int $J$ Livest Res, 2, 3:8992, 2012.

23.Obinna, O. V. M., Emmanuel, O. U., Princewill, O. I., Helen, O., Christopher, Effect of sex and systems of production on the hematological and serum biochemical characters of helmeted guinea fowls (Numida meleagris pallas) in South Eastern Nigeria. Int J Biosci, 1, 3: 51-56, 2011.

24.Nalubamba K. S., Mudenda, N. B., Masuku, M., Indices of health; clinical haematology and body weights of freerange Guinea fowl (Numida meleagris) from the Southern Province of Zambia. Int J Poult Sci, 9, 12: 1083-1086, 2010.

25.Adedibu, I.I., Ayorinde, K.L., Musa, A.A., Identification of hematological markers suitable for improving productivity of Helmeted Guinea Fowl Numida meleagris. Am J Exp Agr, 4, 10:1186-1196, 2014.

26.Sonia C., Rajini R. A., Vairamuthu, S., Haematological parameters of pearl guinea 
fowl influenced by rearing system, age and sex. Ind J Poult Sci, 47, 3: 395-397, 2012.

27. Obese, F. Y., Ali, Z. S., Naazie, A., Ayizanga, R. A., Effect of age, breed and sex on haematological and blood biochemical parameters in helmeted guinea fowl (Numida meleagris). Comp Clin Pathol, 27, 4: 901909, 2018.

28. Oyewale, J.,O., Ogwuegbu, S.,O., Hematological studies on the guinea fowl (Numida meleagris Pallas), Bull Anim Health Prod in Afr, 34:61-65,1986.
29. Orji B.I., Okeke G.C., Akanyiba A.O., Hematological studies on the guinea fowl (Numida meleagris Galeata pallas). I. Effect of age sex and the time of bleeding on the haematological values of guinea fowls. Nig $J$ Anim Prod, 13:94-99, 1986.

30. Uko, O. and Ataja, A. M., Haematological studies of pure indigenous domestic fowl (Callus domesficus) and guinea fowl (Numida meleagris) in North-West Nigeria. Rev Elev Med Vet Des Pays Trop, 49, 3: 257-262, 1996. 